\title{
Tracing the ebb and flow of De Architectura $8^{1}$
}

'Later, a measure (called the quinaria) that was based neither on the inch nor on either of the digits came into use in the City, supplanting earlier measures, either through Agrippa or through the plumbers working under the direction of Vitruvius the architect.' (Frontinus, Aq. 25)

'Vitruvius' eighth book, on water, is not one of his best. It is bitty and discursive... a sloppy compilation of borrowings, largely from Greek writers [which] shows little originality, clear-mindedness or intelligence on Vitruvius' part. His excuse must be that he was old and tired...' (Lewis 1999.145 and 171-2)

When it is discussed at all (which is not often), the eighth book of Vitruvius' De Architectura is frequently approached as something of an anomaly, an interruption almost to the rest of the treatise. Not only does it revolve around the provision of a city's water supply (not one of 'the three parts of architecture' outlined by Vitruvius at $D A 1.3 .1^{2}$ ); it digresses beyond what even an ancient reader might expect an account of civic hydraulics to cover, ranging into philosophy, natural history, geography and paradoxography as it discusses different water types and their weird and wonderful properties. It is a book that surprises both disciplinary and generic expectations in other words, even more than Vitruvius' other books. In addition, it has had the misfortune to disappoint many an archaeologist and historian of technology,

\footnotetext{
${ }^{1}$ I am grateful to the Leverhulme Trust for funding the research fellowship during which this article was written.

2 Aedificatio (building), gnomonice (clock-making) and machinatio (mechanics); McEwen 2003.87-8.
} 
who - without due appreciation of Vitruvius' agenda - have looked to it in vain for a comprehensive treatment of ancient hydraulic practices and techniques; hence critiques like that of Michael Lewis above.

It is perhaps ironic, then, that one of the few ancient references to Vitruvius outside his own treatise associates him first and foremost with plumbing. Of course, in the passage quoted above Frontinus is not referring to Vitruvius' writing but to some of his hands-on experience. It would seem that he may have helped to oversee a significant reform to Rome's water supply system: the introduction of the quinaria. There was some dispute, it seems, as to whether Vitruvius or Agrippa should take the credit (and Frontinus decides in what follows that neither theory sufficiently accounts for the quinaria's name). Whatever the true nature of Vitruvius' involvement, it is clear that in some quarters at least he was remembered for his connection with aqueducts, and even as a figure of comparative significance to Agrippa in that context (despite their difference in status).

I outline this paradox with a view to unpicking both sides of it. The primary aim of this article is to plug a gap in Vitruvian scholarship by offering a close reading of $D e$ Architectura 8. In so doing, I hope to underline what is to be gained by analysing whole books of the treatise as books, to be read through from end to end (something that happens too rarely $^{3}$ ). I will also examine the ways in which Book 8 jigsaws into the rest of the De Architectura. As we will see, far from being an interruption to the wider text, Book 8 proves integral to its exposition of a number of core themes. In fact, it does not simply consolidate but also nuances (for instance) the treatise's

\footnotetext{
${ }^{3}$ Books 9 and (especially) 10 have been the subject of a number of dedicated studies (e.g., Fleury 1993 and 1994; Cuomo 2011); but it has generally been the details of their prescriptions and not the flow of the books that have garnered attention.
} 
representation of architecture and its relationship to the natural world; the relationship that other sections of the text construct between scientific/philosophical learning and architectural/technological know-how; Vitruvius' self-presentation in relation to other scholars and writers; the treatise's literary texture and generic ambitions; and Vitruvius' engagement with Augustan Rome and Augustus himself. My analysis of Book 8 will thus contribute to a number of important areas of current Vitruvian scholarship, because Book 8 itself has new insights to offer into them. Beyond that, it will also draw on and contribute to a wider movement in the study of ancient scientific and technical texts that stresses their intricate intratextuality and the complexity of the reading experiences that they offer. In approaching Book 8 microand macroscopically, I want to draw particular attention to the ways in which ideas and authority - ebb and flow, build up and shift, across the course of the De Architectura.

\section{Prefatory Positioning}

After an introduction that muses on the build-up and refinement of knowledge over time as a result of writing (and sets the De Architectura up as a climax in that story), Book 7 fittingly concludes the treatise's account of the construction of buildings by discussing their refinement, the 'finishing touches' (expolitiones) that must combine 'durability' with 'elegance' (as, indeed, the best kind of commentarii do). Nature supplies the materials, but artifice dominates here even more than elsewhere, as we see time and again how far the accumulated knowledge of pavers, plasterers and (especially) painters can take us from the natural world (and, indeed, from the origins of building outlined at $D A 2.1$ ). In places Vitruvius disapproves of the distance some 
artists have travelled from nature/reality, which perhaps makes it appropriate that, after completing his set of prescriptions on aedificatio, he takes us suddenly back into a more natural, as yet uncultivated landscape: 'in the following book on water I will explain how to find it, if it is absent in some places; how it is to be channelled; and how its safety and suitability can be tested ( $D A$ 7.14.3).'

In fact, the preface to Book 8 plunges us both into what were often regarded as the primordial building blocks of all nature (water, fire, earth and air) and into some of Vitruvius' favourite symbols of high culture, the scholarly traditions that had grown up around them. ${ }^{4}$ In so doing, it recapitulates De Architectura 2.2, another moment in the text where Vitruvius shifts the focus back to the fundamental materials that nature provides, after charting the journey that humankind has taken (via the collective accumulation of knowledge) from primitive life to high civilisation (Romano 1987.130; Novara 2005.141). For it is here, as an introduction to his section on building materials (and after his famous account of the parallel development of architecture and civilised society), that Vitruvius first sketched these age-old theories about the 'foundations of all things'. In kick-starting Book 8 with the natural philosopher Thales (who not only heads his roll-call of theorists at 2.2, but is also first after Homer in his list of sapientes in the preface to Book 7) Vitruvius thus signals the continuity of his hydraulic volume with some of the material that has preceded it. This preface also alerts us to the fact that Book 8 will extend and develop what we have already read, however (rather as the authors in Book 7's preface cumulatively develop and extend the scholarship that has gone before them). For Vitruvius' account of what Thales, Heraclitus and other 'physicists and philosophers' argued is more detailed at

\footnotetext{
${ }^{4}$ Courrént 1999a.534-5 notes Vitruvius' preoccupation with these primordial elements.
} 
the start of Book 8 than the summary he offers at 2.2. The preface to Book 8 justifies Vitruvius' new topic by deploying ancient scientific theories to assert the vital necessity of water (Romano 1987: 132; Novara 2005: 143); but its elaboration of those theories also highlights Book 8's pursuance of the wider scholarly interests promoted in the preface to Book 7, whose contribution to society is celebrated again at the start of Book 9. Far from representing a break in the text's rhythm and agenda, in other words, Book 8 thus flows naturally between Books 7 and $9 .{ }^{5}$ It contributes to Vitruvius' on-going self-promotion as a sapiens scriptor ( $D A$ 9. pr.17) of precisely the kind of commentarius that Books 7 and 9 hail for benefitting humanitas; and it also advances the treatise's presentation of architecture as a learned, intellectual, encyclopaedic (not just functional, technical) activity. ${ }^{6}$

On the other hand, Book 8's preface establishes some breaks in continuity. As many have noted, one anomaly is that alone of Vitruvius' prefaces it does not contain a dedication to the emperor (Callebat 1973.viii; McEwen 2003.87-8; Novara 2005.141). That is particularly striking, given the efforts Augustus was going to with the help of Agrippa to overhaul the city's water supply system (Frontinus, Aq. 98; Pliny NH 36.121). It is possible, in fact, that Vitruvius himself had worked with Agrippa on some of these initiatives (Lewis 1999.145-6). Some have argued that, despite its lack of dedication, preface 8 nonetheless contains some subtle allusions to Augustus and his interests in the water supply (Novara 2005.139-145). The divina mens ('divine spirit'), whose generosity in supplying water so freely to the earth's inhabitants is

\footnotetext{
${ }^{5}$ At 9.6.3 Vitruvius returns once more to the natural philosophers he cites at 2.2 and 8 pr. 1-3 (Callebat 1973.39); see esp. Novara 2005.145 on continuity between prefaces $6,7,8$ and 9 .

${ }^{6}$ Courrént 2002 offers perhaps the best analysis of Vitruvius' assimilation of architecture with other, more elevated sciences/disciplines, but overlooks the role played by Book 8 in this process.
} 
celebrated at 8 pr. 3 , recalls of course the divina mens that is credited at 6.1 .11 with allocating to the Roman people the best and most temperate zone of the earth from which to rule the world. ${ }^{7}$ But it perhaps also evokes the (equally?) omnipotent divina mens of Augustus, whose control of the whole world and care for the life of his subjects is hailed at the very start of Book 1 (1 pr. 1-2). That parallel is not made explicit, however, or exploited as it could have been. In the preface to Book 1 Augustus' public-spirited interest in building is adduced to sanction Vitruvius' publication of the De Architectura as a whole. Here at the start of Book 8, by contrast, Vitruvius passes up the opportunity to assert his new topic's contemporary relevance and turns rather to the authority of 'physicists, philosophers and priests' ( 8 pr. 4), not his emperor, to conclude his justification of a book on water. His failure to repeat the same rhetorical manoeuvre that he deployed in his opening preface, at a point in the text where Augustus' interest in his subject matter might prove particularly valuable, raises questions: about the text's (and Vitruvius') evolving engagement with Augustus; and about the relationship between this book on water supply and the rest of the De Architectura.

Book 8's preface both forges connections and establishes differences, then, between the section it introduces and what has preceded it. Despite its diversion from the structure that readers had been led to expect - its interruption of the text's progress from aedificatio to gnomonice - a network of correspondences is established between Book 8's approach and agenda and those of the rest of the treatise. At the same time, the preface surprises some of its readers' expectations, and in so doing shifts - or at least complicates - our understanding of the De Architectura's identity and objectives.

\footnotetext{
${ }^{7}$ This 'divine spirit' (who, with nature, orders the cosmos) reappears at 9.1.1 and 9.5.4.
} 


\section{Between Nature and Culture in De Architectura 8.1-2}

Studies of Vitruvius' prefaces have done much to enhance our reading of the De Architectura, but they often fail to offer any extended analysis of how the prefaces relate to the books that they introduce. Though the relationship between the eighth preface's philosophical musings and the material covered in the chapters that follow may seem superficial, even strained at first glance, their interaction is a good example of cross-fertilisation between preface and book that repays proper investigation. Indeed, the opening phrase of 8.1 positively invites that, for it both restates and modifies one of the preface's central themes.

Water, it declares, is maxime necessaria et ad uitam ('supremely necessary for life'), an argument already made at 8 pr. $2-3$. However, the sentence goes on to add that it is also 'supremely necessary' et ad delectationes et ad usum cotidianum ('also for pleasure and daily use'). This qualification perhaps picks up on the final sentence of pr. 3 ( where the emphasis on water's necessity and utility gives way to faint glimpses of pleasure and largesse); but it also extends it, not least because it evokes an image of water use that we have already seen in Vitruvius' description of the bathhouse at 5.10 (for while vita suggests the vital quenching of thirst, delectatio and usus cotidianus conjure up the routine purpose and pleasure of bathing). As Victoria Rimell underlines (Rimell 2015), Vitruvian bathhouses have to be attuned to nature specifically, to the natural movement of light and warmth (5.10.1) - and their

\footnotetext{
${ }^{8}$ On the significance of nature in Vitruvius' De Architectura, and the relationship the text establishes between nature and culture/architecture, see esp. Courrént 2011; also 1999a and 1999b.
} 
construction revolves around all the classic primordial elements (earth, fire, water, and air/steam); but (she argues) they are also placed at the centre, the 'high point', of the De Architectura because they represent the culmination of the cultural journey via architecture that Roman civilisation has taken. Vitruvius' bathhouse combines nature and culture, in other words. The opening of 8.1 similarly brings nature and culture into dialogue with each other, in part by alluding to that earlier section. It picks up on the emphasis that the preface to Book 8 has placed on the natural provenance and properties of life-giving water; but it also points ahead to the fact that the book as a whole will go on to cultivate this force of nature in highly civilised and civilising ways. The start of 8.1 thus establishes a thread between the preface and the final endpoint of the book; and it also alerts us to the fact that Book 8 will pursue another theme that other sections of the De Architectura explore - the relationship between nature and (high) culture. Indeed, it will contribute to the treatise's on-going presentation of architecture as the phenomenon that bridges that gap, that constructs complex civilisations out of primitive materials/landscapes, by structuring its discussion of hydraulics as yet another journey from the one to the other.

Uncultivated landscapes dominate to begin with: we are transported first to places where water has yet to be discovered (and therefore where civilisation has yet to put down any roots). Moreover, the instructions we are given for finding water are hardly sophisticated, relying as they do on water/nature to reveal itself to us. The seeker (like the bathhouse) must attune himself to the movements of the sun and work with, not against, the natural terrain (8.1.1); and his role is primarily an observational one, to deduct from what he sees of soil types (8.1.2) and vegetation (8.1.3) what quantity and quality of water may flow nearby. Even when a possible supply is detected, the methods for testing it revolve around natural processes - condensation, absorption and 
evaporation (8.1.4-5) - and, indeed, around the almost autonomous interactions of the four basic elements of earth, water, fire and air that dominate the preface. All that man can do is capitalise on a water source when one is discovered, by sinking individual wells - or a network of channels if a 'head' of water is found (8.1.6, an image we will come back to). And the closing section of 8.1 further underlines nature's mastery (and man's relative impotence), as it explains that water from mountainous and northern regions is always 'sweeter, healthier and more abundant', while areas exposed to 'the violent force of the sun' yield far less water, of a sort that tends to be harsh and unpleasant. This passage recalls 6.1 of course, where Vitruvius again discusses the differences between northern and southern climates. Significantly, however, that earlier analysis is framed by a repeated assertion (at 6.1.2 and 6.1.12) that architecture can temper some of the effects of climate. 8.1.6-7, by contrast, is more fatalistic about nature's supremacy and offers no architectural or hydraulic solutions to deflect its impact on a region's water quality.

That said, this very topic rehearses some long-standing scientific, meteorological, geographic and anthropological debates (Callebat 1973.60-3), and in so doing reminds readers of the scholarly sophistication of Vitruvius' treatise. And as Book 8 presses on, it is less nature itself and more the study and cultivation of it that comes to the fore. At 8.2, for example (where some theories about rainfall are sketched), the four primordial elements can be seen in action again, triggering evaporation, cloud formation and precipitation. Nature is at work; but the increased technicality of Vitruvius' language alerts readers to the increased complexity of the arguments he is outlining - that is, to his treatise's (and society's) increasingly knowledgeable grasp 
of the workings of nature. ${ }^{9}$ Moreover, he transports us back to the bathhouse to reexplain evaporation (8.2.4). Once again we find ourselves soaking up the atmosphere of this highly cultured space; but this time our eyes are directed to the ceiling not to admire the stucco work nor to visualise the engineering that goes into the structure behind it (5.10.3) but to watch water drops collecting on it and dripping down onto the heads of bathers below. That image reinforces both Vitruvius' instructions at 5.10.3 for properly water-proofing a bathhouse ceiling (lest the moisture from the steam rot the construction materials) and also the power of water and the other primordial elements (not least because it segues straight back into a discussion of cloud formation). At the same time, however, it offers another glimpse of humans harnessing these natural processes in the most sophisticated - technical and cultural ways. Finally, the conclusion of this section moves through wind (8.2.5) to rivers (8.2.6-8) - more great forces of nature - and in so doing brings us onto geography and cartography. For in returning to his argument that the north is a superior source of fresh water, Vitruvius draws on and shows off his knowledge of some long-standing geographical theories. ${ }^{10}$ In fact, whether or not he was familiar with Agrippa's mapmaking endeavours, he also taps into a contemporary interest in world-charting here (Nicolet 1988.134-5; McEwen 2003.20-2), and sketches out a textual map of his own.

Over the course of 8.1-2, in other words, the text oscillates between nature and culture as its preface suggested it might, developing the wider text's exploration of these phenomena and their interaction with each other. There is an ebb and flow of mastery between the two, but the momentum is towards the expansion and refinement that increasing levels of culture bring, as we progress from water-sourcing in uncharted

\footnotetext{
${ }^{9}$ On Vitruvius' use of a mixture of linguistic registers in Book 8, see Callebat 1990.

${ }^{10}$ Bommelaer 1989.25-8 notes Vitruvius' somewhat shaky grasp of some of these theories.
} 
landscapes to a learned word-picture of nature's greatest water sources that takes us across the known world and into disciplines and genres that a volume on how to find, channel and test water might not be expected to embrace. In the preface to Book 7 Vitruvius famously accentuates his celebration of the contribution that learned authors have made to society (and his own treatise) by comparing the enriching flow of scholarship to the pooling of (re)sources and the drawing of water from multiple springs ( 7 pr. 10, another image - like that of the bathhouse at 8.2.4 - where nature and culture are reflected back at each other). Here, in this book that begins with the challenge of finding individual sources of real, nourishing water (and recommends early on that if a particularly abundant supply is discovered, several wells are to be sunk so that a series of channels can bring it all to one place: 8.1.6), that simile cannot be lost on us, as Vitruvius' literary and scholarly sources proliferate and his own work becomes increasingly richly-stocked.

\section{Muddied Waters in De Architectura 8.3}

'There are in fact a number of hot springs from which excellent-tasting water flows; indeed, such water is so sweet to drink that one would miss neither the Fountain of the Camenae nor the free-flowing Marcian aqueduct.' (8.3.1)

It can be no coincidence that at the start of 8.3 Vitruvius mentions the 'Fountain of the Camenae', a natural spring on Rome's Caelian hill but also, of course, a site whose name evokes literary activity (the Camenae being identified with the Muses). Here, if we needed it, is an extra hint that we are to carry forward Vitruvius' scholarly spring simile from Book 7 into his discussion of real springs in Book 8. Equally significant is 
the fact that Vitruvius' mention of this fountain pairs it with a famous piece of Roman hydraulic engineering, as if the two are on a par with each other: a spring that generates thought of the Muses is mentioned in the same breath as Rome's most salubrious aqueduct - the Aqua Marcia, which underwent restoration in 33BC (Pliny NH 31.41; Frontinus Aq. 7 and 91) - bringing literary and technological endeavour together. The opening of 8.3, in other words, presents the world of learned writing and the practice of water-channelling as parallel symbols of civilisation - in explicit contrast to naturally occurring phenomena (the fontes calidi with which they are compared). That paves the way for the transition that will follow from the exposition of natural science, meteorology and geography (8.1-3) to the more technical half of Book 8 (8.4-6). But it also supports the claim that the De Architectura repeatedly makes elsewhere (particularly at 1.1) that architecture as a whole does not just incorporate but is of equal status to more traditionally elevated scientific, philosophical and literary disciplines.

The close of 8.3 further underscores the continuity that other parts of the treatise insist upon between learning/scholarship and technology/architecture. 8.3 is one of the longest, most meandering sections of the treatise (a point we will return to), and in the course of it (even more than in 8.1-2) we are taken all over the globe, and into paradoxography, medicine, mineralurgy and metallurgy as well as natural history and geography, as we are shown the strange properties that different water sources can have (Callebat 1988; Courrént 2004.271-8). We even stray into myth and Greek poetry when Vitruvius cites three epigrams engraved near different springs, warning potential drinkers to beware of their waters (8.3.21-3). Shortly afterwards, we are presented with a snapshot of Vitruvius at home, engaged in learned conversation: 
'Gaius Julius, the son of Masinissa, who owned all the land belonging to the town, fought on the side of Julius Caesar. He was often my guest. As a result, in our daily intercourse we often found ourselves debating matters of scholarship (philologia). Once, when the potency of water arose as a topic between us, he told me that in his country there were some springs that gave those who were born in the area amazing singing voices...'

Philologia, of course, is the pastime of great kings, not least those members of the Attalid dynasty who established the great library at Pergamum that Vitruvius holds up as a beacon of cultural development in the preface to Book 7. It also characterises the future readers of Lucretius, Cicero, Varro and nameless Greek philosophers (and, by implication, also Vitruvius himself), who are imagined in the preface to Book 9 deliberating across time with their knowledgeable predecessors (9 pr. 17). Philologia, in other words, is a buzz-word in the treatise for the highest form of learning; indeed, it is precisely what Vitruvius represents as the culmination of his own 'encyclopaedic' education in the preface to Book 6.

In fact there (at 6 pr. 4) he thanks his parents and teachers for supplying him with the 'stores of knowledge' that taught him to delight in both philologis et philotechinis rebus ('literary and technical matters') - another moment in the treatise when these two spheres are placed on a continuum with each other. It is therefore appropriate that at the end of 8.3 , when he recalls that passage from Book 6 with a parallel image of himself (still) indulging his passion for scholarship, he is in the process of transitioning from philologis to philotechinis rebus. The section climaxes with another list of Vitruvius' sources (8.3.27), which (as in the preface to Book 7) underlines not just Vitruvius' personal commitment to scholarship but also his De 
Architectura's place in (at the culmination of) a long-standing tradition of learning and literature. However, the list is also a device that enables Vitruvius to segue smoothly into the technical nitty gritty of Book 8; for he proceeds to draw a straight trajectory from the efforts of these recorders of marvels to what he is working towards in Book 8:

'...Following in their footsteps I have written as much in this book as I thought necessary about the varieties of water, so that on the basis of these prescriptions men might more easily select springs of water from which conduits may be drawn for the supply of cities and towns.' (8.3.27)

As at the end of his list of sources in the preface to Book 7, Vitruvius emerges here as innovative, not merely derivative. For while the authors in whose footsteps he follows may have contributed to civilisation by helping to build up learning about water, Vitruvius stands out for uniting that project with the physical construction and supply of civitates. ${ }^{11}$ It is worth noting, too, that just before he lists his textual sources, he states (with significant emphasis in the Latin on his personal agency): 'A good number of these facts I discovered myself'. This phrase may remind readers of Vitruvius' hands-on experience of civic hydraulics, again connecting the seemingly arcane scholarship that he has been sketching to a more concrete, technical reality. For all its apparent discursiveness, in other words, 8.3 does much to establish links between Book 8 and other sections of the De Architectura which bring the worlds of learning and architecture - and writing and doing - together.

${ }^{11}$ Harris-McCoy (forthcoming) discusses the distance that Vitruvius establishes between the authors he cites as sources and his own treatise. Vitruvius' insistence at 8.3.27 that all of his textual sources are Greek furthers the suggestion that he and Book 8 are somewhat ground-breaking (cf. 7 pr. 14-18). 
That said, culture (as embodied by both learning and architecture) does not triumph here. The final paragraph of 8.3 returns us to a theme of the preface, the vital necessity of water - which again evokes the power of nature: life cannot originate or survive without it (8.3.28). The closing sentence then extrapolates from that an insistence on the 'great diligence and industry' that must therefore be applied in 'choosing springs for the health of mankind' (Quare magna diligentia industriaque quaerendi sunt et eligendi fontes ad humanae vitae salubritatem; this parallels - but also supplants - the vigilantia et infinito studio that V's literary sources were credited with at 8.3.27). This is an elaboration of what Vitruvius has just claimed Book 8 can help readers with (the selection of water sources: 8.3.27: eligant ...aquae fontes; 8.3.28: eligendi fontes), and therefore a reiteration of the value of this volume and the role it promises to play in bridging the gap between water-sources and civilisation or nature and culture. However, the emphasis that is placed here on salubritas, together with the lowering, negative image he has just painted of (a lack of) life without water, also drums home a point that 8.3 as a whole makes very powerfully: that (no matter how sophisticated his learning) man's relationship with nature remains precarious. For, though we start 8.3 with natural springs of the most excellent flavour (that put even the manmade aqua Marcia in the shade) we see example after example of water sources that are noxious; indeed, water that threatens to undermine great civilisations.

Nature's primordial elements are at work from the start: at 8.3.1 it is fire heating earth and giving rise to vapours which then mix with water that causes some springs to taste particularly sweet; but precisely the same set of forces in a different combination are equally capable of giving water a foul flavour and smell (8.3.2). Some waters can heal (8.3.4-5) or give a delicious aroma to vines (8.3.12-13); but others turn white cows 
red (8.3.14), or cause gout (8.3.5), tooth-rot (8.3.23), inebriation (8.3.20), imbecility (8.3.22), and even death (8.3.15-17) - a theme that Vitruvius dwells on at particular length. In an echo of the book's preface, we are invited to marvel at nature's amazing variety (especially at 8.3.26); but instead of generating a sense of gratitude (as at 8 pr. 3), 8.3 has a tendency to inspire bewilderment - not least because it meanders unpredictably from location to location, genre to genre, and topic to topic (touching now on wholesome water, now on harmful sources, then back to salubrious supplies, and so on). In fact, the very incontinence and lack of organisation in the fabric of the text at this point might be read as a metaphor for what 8.3 teaches us: that water is beyond our complete control. Baffled by its properties, men make mistakes in their hydraulics (8.3.3), and even great cities like Athens and Troezene prove unable to overcome the poor quality of some of their sources (8.3.6). ${ }^{12}$ Thus rather than testifying to man's ability to take charge of water, 8.3 exposes the limits of civilisation. It is both bettered by nature (as the comparison between the naturally occurring hot springs, the fons Camenarum and the aqua Marcia at the start suggests) and potentially undermined by it. Philologia and water technology (two symbols of high culture) may be united at the beginning and end of 8.3 , but the potency of water (aquae potestas) and other powerful forces of nature also frame and ultimately dominate the section. ${ }^{13}$

That is a message that is not simply challenging for civilisation generally but for Augustan Rome specifically. It should be more often recognised that, for all its aspirational celebration of modern (as opposed to primitive) culture, cracks regularly

\footnotetext{
${ }^{12}$ See also 8.3.10, where we see irrigation (a sign of civilization) being complicated by the natural properties of the local water.

${ }^{13}$ Indeed, they dominate the book, thanks to the imbalance between the space devoted to mirabilia aquarum and that given over to civic hydraulics. McEwen 2003: 88 notes that water is the enemy of coherence (and architecture) in Book 2.
} 
appear across the De Architectura between ideals and reality. Architecture as a discipline may theoretically be at its zenith, for instance, but the text also acknowledges that it is constantly being corrupted by ignorant patrons and unscrupulous practitioners (e.g., 6 pr. 5-7; 10 pr. 2). Learning and literature, meanwhile, are also under threat from charlatans (7 pr. 3-9); and, Vitruvius' efforts notwithstanding, the Latin literary scene is still some way behind its Greek counterpart (7 pr. 14-18). In addition (as I argued in König 2009) Vitruvius' interaction with Augustus is not as straightforward or supportive as some have supposed: the De Architectura engages with the rhetoric of the new principate not merely to regurgitate but also to explore and exploit it, and insists on an overlap between architects and emperors that is as unsettling as it is ambitious. Towards the end of Book 10, in fact, it narrates an episode from the recent civil wars when Julius Caesar's forces were outwitted by clever architectural engineering (10.16.11) - one of a series of stories that builds up to a climactic image of architects (not emperors) as triumphant military strategists. The treatise is thus framed by images of Augustus at the start and architects at the end winning great victories (not least over Rome's first would-be emperor) that together expose the to-and-fro of conflict and keep open the possibility that the great global conquest we celebrate at beginning of the treatise is only the latest in an on-going series of tussles between competing forces. ${ }^{14}$

As I noted above, the preface to Book 8 is unusual in paying no explicit tribute to Augustus. 8.3.25, however, contains another reference to Julius Caesar and the civil wars; for Vitruvius strikingly (and somewhat redundantly) introduces his house-guest Julius Gaius first of all in terms of whose side he fought on in that conflict. ${ }^{15}$ Book 8

\footnotetext{
${ }^{14} \mathrm{Cf}$. Cuomo 2011:321-4 for a different reading of this episode.

${ }^{15}$ On Julius Gaius’ identity: Callebat 1973: 127-8; Baldwin 1989: 12.
} 
does make explicit reference, then, to near-contemporary politics; but like 10.16 .11 , it takes us back to a more unsettled time before Augustus' divina mens et numen had taken control of the world - indeed, before anyone had any inkling that it might. Together with Augustus' absence from the preface, that might prompt us to read an extra significance into the dominance of nature at 8.3 - which is characterised, as we saw, as another omnipotent divina mens not just in the preface to Book 8 but also at 6.1.11, where it has some significant political influence; indeed, where it effectively decides which nation gets to rule the world. ${ }^{16}$ Augustus, Agrippa (and even Vitruvius) may be pushing through various water supply reforms as part of the regeneration of Rome as an imperial capital and Augustus' consolidation of his own newly acquired potestas (Grimal 1945.170-1); but the tenor of 8.3 suggests that even these authority figures (and perhaps imperial Rome itself) are no match in the end for a greater and ultimately capricious power. In view of Augustus' and Agrippa's investment in civic hydraulics, in other words, the dynamic that 8.3 establishes between nature and science/technology has potentially political implications. ${ }^{17}$ Indeed, it may play a part in a development across the whole of the treatise that sees the extent and stability of Augustus' imperium increasingly questioned. The book's oscillation between nature and culture does not just complicate the wider treatise's exploration of these interrelated phenomena; like Vitruvius' failure to salute Augustus and his hydraulic endeavours in the preface, it subtly adjusts the De Architectura's engagement with its imperial addressee.

\section{Supplying Civilisation(s): De Architectura 8.4-6}

\footnotetext{
${ }^{16}$ Courrént 1999b: 6-7 discusses the overlap in Vitruvius (and Stoic thinking generally) between natura and this divina mens.

${ }^{17}$ McEwen 2003.88 hints obliquely at this.
} 
The ebb and flow between nature and civilisation continues even in the more technical half of Book 8. Section 8.4 moves into instructions and, up to a point, solutions for some of the challenges thrown up by 8.3, as Vitruvius transitions from his scholarly to his more technically expert persona. The return to a more technical topic (methods for testing the quality of water) is signalled by the recapitulation of vocabulary found at the start of 8.1, linking disparate parts of the book and carrying forward its momentum from the discovery of water to its delivery. As before, however, the architect's activity is limited to passive observation (nature remains in charge), and the techniques suggested are extremely basic: we are advised, for example, to draw conclusions from the physique and complexion of the locals, or to see what residue is left after boiling to assess the quality and safety of a newly discovered source. For all the learning of $8.2-3$, we go back in 8.4 to deducting somewhat precariously from mere appearances. One indication that water is bonam et salubrem is the speed with which vegetables can be cooked in it, a culinary method that hardly smacks of sophistication, and which (more significantly perhaps) confronts us again with the prospect of ingestion: a potentially hazardous enterprise, as we know after the consumption of so much unsafe water in 8.3 . The section ends with the phrase 'water is shown by these signs to be... extremely wholesome' (in summa salubritate), vocabulary that - in its echo and development of the wording at the end of 8.3 (...ad humanae vitae salubritatem) - gives the impression of having made progress, from the need to find water to the identification of the healthiest sources. The brevity of 8.4 , especially in contrast to the meanderings of 8.3 , however, combines with the limitations of its instructions to leave the reader feeling potentially under-equipped. As we move (all too) swiftly on in 8.5 to the channelling and delivery of what is essentially still 'potluck' water, we could be forgiven for feeling 
that we have rather glossed over, not solved, the challenges of sourcing safe supplies that 8.3 made so much of.

8.5 moves us forward again, not only by turning to the topic of delivery but also by establishing a link between the subject of Book 8 and the wider trajectory of the rest of the treatise: 'Now I will explain how water is to be channelled to dwelling places and towns.' The phrase de perductionibus ad habitationes moeniaque (8.5.1) points us back (and forwards) towards city building as we near the end of the text's hydraulic interlude, reinforcing the latter's relevance at the same time as indicating that we are on our way to rejoining the main thrust of the text. At this point, the technicality of Vitruvius' language steps up a notch, enhancing his authority as a hydraulic expert. Specialist vocabulary abounds as he compares methods of 'levelling' with dioptrae, 'water weights' and chorobates. His preference for doing things diligentius (i.e. with chorobates) recalls the emphasis placed on magna diligentia industriaque when the searching out of salubrious sources was discussed (8.3.28), tying the two endeavours and sections together. The language of ratio and Vitruvius' insistence on accuracy and symmetry at 8.5.1, meanwhile, establishes consistency between his hydraulic prescriptions and the approach he adopts when discussing other aspects of architecture elsewhere in the treatise, helping to weave his hydraulic and architectural personae more firmly together.

Nature (again in the form of its primordial elements) raises its potentially disruptive head: the wind can occasionally interfere with the process of levelling (8.5.2); the curvature on the surface of water has the potential to complicate it (8.5.3); and marshy terrain sometimes presents challenges. In contrast to 8.1, however, where Vitruvius was fatalistic about nature's power, here at 8.5 technology triumphs. The building of 
'substructures' can be deployed where land is marshy; the use of a spirit-level (of sorts) can deal with wind; and Vitruvius is confident enough in the method he is advocating to assert that, despite Archimedes' theories about the curved surface of water, true levelling can nonetheless be achieved. Archimedes is hailed elsewhere, of course, as one of history's greatest scientific thinkers: for instance, at 1.1.17, where he is listed amongst a very select number of scholars on whom nature has bestowed so much sollertia, acumen and memoria that they have been able to master a multiplicity of different disciplines (the architectural ideal); and also in the preface to Book 9, where his famous discovery in the bath of hydrostatics is narrated at some length. ${ }^{18}$ Vitruvius' confidence in overriding another of his water-based theories at 8.5.3 is therefore striking, and helps to establish Vitruvius not just as a student of science himself but as a hydraulic expert who is moving beyond the work even of his most illustrious scholarly predecessors. Civil engineering does not simply triumph over nature here; Vitruvius' technical know-how confronts and revises the celebrated theories of earlier scientific thinkers. (And, as always in this text, didactic/practical and intellectual/literary agenda bubble away alongside - in collaboration as well as competition with - each other.)

In 8.6, too, technology (of a particularly modern, indeed conspicuously Roman variety) appears to triumph, and Vitruvius' hydraulic and architectural expertise again builds on and moves beyond more abstract science, indeed the very tenets of natural philosophy around which his scholarly authority was constructed at the start of the book. If technical minutiae abounded in the previous section, they positively flood the text here, as Vitruvius describes not one but three different methods of water supply

\footnotetext{
${ }^{18}$ See also 1.1.7 (where Archimedes is again associated with hydraulic learning and writing) and 7 pr. 14; also Courrént 2008 on Vitruvius' use of Archimedes as an exemplum.
} 
(canals, lead conduits, and earthenware pipes). Detailed prescriptions are set out for channel building, tunnel digging, supply routes, network configurations, and pipe lengths, widths and weights. The problems posed by terrain (hills, valleys, uneven flow), natural processes (evaporation, corrosion) and the laws of physics (water force, air pressure) are anticipated and deflected by additional instructions; and this combines with the methodological presentation and a wealth of specialist terminology to lend the discussion an air of authoritative comprehensiveness. It also grounds the book more firmly (especially after the philosophising and mythologizing of 8.1-3) in concrete practice. In fact there may even be hints at Vitruvius' own practical experience here (especially at 8.6.2, where a verb in the first person singular constituerim - intrudes to explain the administrative reasoning behind his prescriptions on distribution channels ${ }^{19}$ ); and these not only enhance the authority of his instruction but suggest that it embodies some of the latest hydraulic methods and practices. ${ }^{20}$ The water-supply simile that Vitruvius deployed in the preface to Book 7 to characterise the flow of knowledge from one generation to another ( 7 pr. 10) may spring to mind again, as we see literal channels of water pooling and even overflowing in reservoirs (8.6.1; compare 7 pr. 10's abundantes... copias) and then being divided and distributed for a variety of uses (8.6.2; again, compare the image at 7 pr. 10 of different authors drawing on metaphorical supplies to use them ad propria proposita). For there is an obvious parallel with what the text itself is doing at this point, in both collating and disseminating so much (vital) information.

The life-giving - or at least life-preserving - nature of Vitruvius' instructions is heightened by further reference to some of the hazards involved in establishing a

\footnotetext{
${ }^{19}$ On this, see Callabet 1973: xxxviii; Lewis 1999: 146; Hodge 2002: 280-2.

${ }^{20}$ Even Lewis 1999 accepts that some of Vitruvius' prescriptions reflect contemporary (as opposed to earlier Greek) practices.
} 
water supply system. At 8.6.10-11, for example, the harmful properties of lead piping are discussed. Once again, the language of salubritas comes to the fore, to be matched and challenged by more threatening vocabulary (vitiosus, nocens) that recalls earlier sections of the book where the wholesomeness of water also proved a thorny subject. The problem-solving momentum of the latter half of the book persists, however, as earthenware pipes are promoted as a simple alternative. 8.6.12 also points us back towards earlier sections, for we turn our attention here from the construction of artificial conduits to the digging of wells, a topic touched on at 8.1.6. There the sinking of wells was presented as a straightforward task; at 8.6.12, by contrast, we are confronted once more with the primordial forces of nature and warned to be wary of them - indeed, to employ 'intelligence and great expertise' (the hallmarks of the ideal architect) in dealing with them (acuminibus sollertiaque magna naturales rerum rationes considerandae). For (we are told) soil has many different things in it, and like everything else consists of four principles (earth, water, heat and vapours), some combinations of which can choke and even kill well-diggers. As in the case of Vitruvius' description of the effects of lead-poisoning on the body, the imagery he employs here is shocking, even gruesome: nature's basic elements are seen invading the body. Air, fire, earth and the quest for water - celebrated in the preface to Book 8 as essential to all life - emerge (not for the first time) as potentially deadly phenomena. And yet - once again - the challenges posed by these formidable naturales rerum rationes are met by technological rationes (8.6.13): specifically, the use of lamps for testing for subterranean vapours and the construction (if necessary) of vents for their release. Knowledge of natural science (as embodied by the primordial elements) is shown to be vital (not mere prefatory, abstract icing on an 
otherwise less palatable cake), ${ }^{21}$ but it is also surpassed by (not merely paired with) architectural know-how.

Moreover, the section (and book) concludes by combatting nature in two further ways which again foreground a combination of hydraulic and architectural expertise. Should the terrain prove too hard for well-digging, for example, Vitruvius recommends the collection of water from roofs or higher ground - an age-old practice, but one brought up-to-date here by the supply of a recipe and installation instructions for cisterns made from opus signinum, a kind of mortar that was almost certainly a relatively recent Roman invention. The use of multiple storage cisterns is also recommended, to allow water to percolate and sediment to settle, resulting in a supply that is multo salubriorem et suaviorem ('much healthier and sweeter'); and failing that (we are told, in the final instruction of the book), salt can be added to make water more 'fine' (extenuari). Reference to suavitas as well as salubritas returns us to 8.1 (not just 8.3), where we encountered springs that were naturally sweet (in some cases as a result of natural percolation processes: 8.1.2); here at the close of the book, after a deal of anxiety en route about water sources of dubious quality, Vitruvius finally outlines some artificial practices that might more consistently do what nature only intermittently does: supply water that is salubris. The momentum of the second half of Book 8 thus gradually builds to suggest that a city under Vitruvius' care need not be in quite the same position at Athens or Troezen (8.3.6), who have no control over the water they are supplied with. The power of nature's divina mens is not underestimated; but over the course of the volume we are shown ways in which

${ }^{21}$ Cf. $D A 1.1 .7$ where Vitruvius first makes that point, specifically in relation to water supply, as part of his outline of the different disciplines architects need to be familiar with. 
architectural acumen and sollertia (occasionally of a particularly contemporary, Roman variety) can overcome it.

\section{The ebb and flow of ideas and authority}

De Architectura 8 does not simply teach us about the supply of water to towns and cities, then. Nor it is an aberration from the rest of the treatise (let alone a 'sloppy compilation...'). Rather, it is a book whose ebb and flow of ideas plays an important role in moving the De Architectura as a whole on, in developing some of its core themes and shifting readers' understanding of them. It does not merely reinforce the relationship sketched elsewhere between nature and technology/architecture, but complicates it, emphasising the to-and-fro - the on-going tussle, indeed - between these two powerful forces. ${ }^{22}$ Similarly, it does not simply endorse links that other sections establish between architectural/technological know-how (and practice) and (more abstract) scientific/philosophical learning, but introduces more competition between the two, with the former increasingly building on - and becoming authoritative beyond - the latter. In the process (and via the complex interplay that builds up between images of nature's powerful divina mens, assertions of architects' acumen and sollertia, and the striking occlusion of Augustus and Agrippa from the text) Book 8 adjusts the relationship that the wider work constructs between Vitruvius and his imperial patron(s), preparing us for the final denouement in Book 10, where the sollertia of architects triumphs even over imperators.

${ }^{22}$ Cf. Courrént 1999a and 1999b, which argue that Vitruvius' establishes a smoother relationship between nature, natural science and architecture/technology than the one I outline. 
Of course, Book 8 does much more besides: in a longer version of this article, I would want to look more closely (for example) at the way in which its polyphony of styles and registers expands the generic parameters of the treatise as a whole, shifting assumptions about the text's aspirations vis-à-vis other kinds of writing; I would also highlight the new questions that Book 8 raises about the identity and agenda of the $D e$ Architectura's readers, and the ways in which its internal momentum adjusts the balance (or tension) between technical and intellectual agenda across the wider work. More than anything, however, my reading of Book 8 aims to underline the complex intratextuality of the De Architectura. Vitruvius' insistence that he is writing a definitive corpus architecturae ('body of architecture') has been much picked over, but it has perhaps led to a rather skewed appreciation of the way in which the text works. Superficially, at least, the treatise's disparate parts do indeed build up (rather as the different parts of a Vitruvian building are meant to) to form a balanced, neatly proportioned, seemingly perfect whole. Underneath that tight organisation, however, all sorts of currents run backwards and forwards, bringing different parts of the treatise into dialogue with each other in ways that adjust and even contradict (rather than simply consolidating) the idea(1)s that they generate. ${ }^{23}$ This can only be appreciated by through-reading, of individual books and the text as a whole, but it is essential to a proper understanding of the often quite complicated, even tangled trajectories that different themes take throughout the De Architectura.

A final word on that quotation from Frontinus' De Aquis, whose association of Vitruvius with plumbing has generated a particular interest in De Architectura 8 - but also led sometimes to the kind of frustration that Michael Lewis expresses. One

${ }^{23}$ Cf. Callebat 1989 on the tensions that emerge between the text's macroorganization and the meanderings of different books. 
reason why Frontinus cannot be sure who introduced the quinaria to Rome is that Vitruvius does not foreground his own hydraulic activities in Book 8. In fact, he chose a more subtle and arguably far more effective route to fama, in keeping with the approach he adopts in the rest of the treatise: rather than spelling out some of his individual activities, which can only have reinforced his relatively lowly status, he represents the supply of water (as he does other parts of architecture) as a vital, learned, technically sophisticated and powerful undertaking (the language of potestas recurs again and again) that only the most astute (sollers) of architects can get right. That not only promotes him; implicitly it also relegates less highly trained figures (not least Agrippa, and perhaps even Augustus) to a category of 'builder' that appears elsewhere in the treatise in a less than favourable light: the uninformed patron or the overseer in need of (Vitruvius') expert guidance. It may have been these rhetorical manoeuvres, across and beyond Book 8 - and not just Vitruvius' hands-on involvement in civic hydraulics - that inspired Frontinus to identify him, and pass him on to posterity, both as an 'architect' and as a figure who could be compared with Agrippa in (at least one chapter of) the history of Rome's water supply. Since before the time of Frontinus, in other words, Book 8 may have played a role from within the wider body of the De Architectura in defining who Vitruvius was and in influencing approaches to himself and his treatise. It is therefore fitting, in a volume that aims to reappraise Vitruvius 'in the round', to reassert Book 8's significance for future studies of this extraordinary text.

Alice König (St Andrews) 


\section{Bibliography}

Baldwin, B. (1989) 'The non-architectural side of Vitruvius', Prudentia 21.2: 4-12

Bommelaer, J.-Fr. (1989) 'Sur les rapports de Vitruve avec le science de son temps: questions de topographie et de géographie', in H. Geertman \& J.J. de Jong (eds) Munus Non Ingratum. Proceedings of the International Symposium on Vitruvius' De Architectura and the Hellenistic and Republican Architecture. Leiden 20-23 January 1987, Leiden: 22-30

Callebat, L. (1973) Vitruve, de l'Architecture, Livre VIII. Collection des Universités de France, publiée sous le patronage de l'Association Guillaume Budé, Paris (1988) 'Science et Irrationnel - Les mirabilia aquarum', Euphrosyne 16: 155-

67

(1989) 'Organisation et structures du De Architectura de Vitrvuve', in H.

Geertman \& J.J. de Jong (eds) Munus Non Ingratum. Proceedings of the International Symposium on Vitruvius' De Architectura and the Hellenistic and Republican Architecture. Leiden 20-23 January 1987, Leiden: 34-8 (1990) 'Le vocabulaire de l'hydrologie et des sciences auxiliaires dans le livre VIII du De Architectura de Vitruve', Voces (Revista de Estudios de Lexicología Latino y Antigüedad Tardía) 1: 9-22

Courrént, M. (1999a) 'Equilibre et changement dans le De Architectura de Vitruve: méchanique et chimie du monde appliquées à l'architecture', Latomus 58 (3): $534-63$

- (1999b) ‘A propos d’une polysémie problématique; étude sémantique et lexicologique de natura dans le De Architectura de Vitruve', Les Etudes Classiques 67: 3-20 (2002) 'La construction du savoir par la confrontation interdisciplinaire: 
l'imaginaire vitruvien', in M. Courrént \& J. Thomas (eds) Imaginaire et modes de construction du savoir antique dans les textes scientifiques et techniques: actes du colloque de Perpignan, 12-13 Mai 2000, Perpignan: 12343

(2004) “ “Non est mirandum”: Vitruve et la résistance à l'étonnement', in O. Bianchi \& O. Thévenaz (eds) Mirabilia: Conceptions et representations de l'extraordinaire dans le monde antique: actes du colloque international, Lausanne, 20-22 mars 2003: Berne: 265-78

- (2008) “ "Eurêka, eurêka": Archimède et la naissance de la mythologie des sciences', Pallas 78: 169-83 (2011) De Architecti Scientia. Idée de nature et théorie de l'art dans le De architectura de Vitruve, Caen

Cuomo, S. (2011) 'Skills and Virtues in Vitruvius Book 10', in M. Formisano \& H. Böhme (eds) War in Words. Transformations of War from Antiquity to Clausewitz, Berlin: 309-332

Fleury, P. (1993) La méchanique de Vitruve. Caen (1994) 'Le De architectura et les traités de méchanique ancienne', in Le Projet de Vitruve. Objet, destinataires et reception du De architectura. Actes du colloque international, Ecole française de Rome, Rome: 187-212

Grimal, P. (1945) 'Vitruve et la technique des aqueducs', $R P h$ 19: 162-74

Harris-McCoy, D. (forthcoming) 'Making and Defending Claims to Authority in Vitruvius' De Architectura', in J. König \& G. Woolf (eds), Authority and Expertise in Ancient Scientific Culture, Cambridge

Hodge, A.T. (2002) Roman Aqueducts and Water Supply, London, $2^{\text {nd }}$ edn.

König, A.R. (2009) 'From architect to imperator: Vitruvius and his addressee in the De Architectura', in L. Taub \& A. Doody (eds), Authorial Voices in Greco- 
Roman Technical Writing, Trier: 31-52

Lewis, M. (1999) 'Vitruvius and Greek Aqueducts', PBSR 67: 145-72

McEwen, I.K. (2003) Vitruvius; writing the body of architecture, Cambridge Mass.

Nicolet, C. (1988) 'De Vérone au Champs de Mars: chorographia et carte d'Agrippa', MEFRA 100 (1): 127-38

Novara, A. (2005) Auctor in Bibliotheca. Essai sur les textes préfaciels de Vitruve et une philosophie latin du Livre, Louvain

Rimell, V. (2015) The Closure of Space in Roman Poetics. Empire's Inward Turn, Cambridge

Romano, E. (1987) La Capanna e il Tempio: Vitruvio o dell'Architettura, Palermo 